\title{
Analysis of ribulose bisphosphate carboxylase gene expression in natural phytoplankton communities by group-specific gene probing
}

\author{
S. L. Pichard ${ }^{1}$, L. Campbell ${ }^{2, *}$, K. Carder ${ }^{1}$, J. B. Kang ${ }^{1}$, J. Patch ${ }^{1}$, F. R. Tabita ${ }^{3}$, J. H. Paul ${ }^{1, * *}$ \\ ${ }^{1}$ Department of Marine Science, University of South Florida, St. Petersburg, Florida 33701, USA \\ ${ }^{2}$ Department of Oceanography, School of Ocean and Earth Science and Technology, University of Hawaii, Honolulu, \\ Hawaii 96822, USA \\ ${ }^{3}$ Department of Microbiology and the Plant Molecular Biology and Biotechnology Program, The Ohio State University, \\ Columbus, Ohio 43210 , USA
}

\begin{abstract}
To understand the composition and photosynthetic carbon fixing activities of natural phytoplankton communities, we employed group-specific ribulose bisphosphate carboxylase (RubisCO) large subunit gene probes $(r b c L)$ to examine RubisCO gene expression. The $r b c L$ genes from Synechococcus PCC6301 (cyano) and from Cylindrotheca sp. (chromo) were used as probes at select stations to examine levels of $r b c L$ mRNA in specific size fractions ( $>5 \mu \mathrm{m}, 1-5 \mu \mathrm{m},<1 \mu \mathrm{m}$ ) in surface waters of the mouth of Tampa Bay (estuarine), West Florida Shelf (coastal), and from the offshore Gulf of Mexico. Using DNA purified from algal isolates, we demonstrated that the cyano probe was specific for the chlorophyte/cyanobacterial RubisCO evolutionary lineage and the chromo probe was specific for the chromophyte evolutionary lineage /diatoms, prymnesiophytes, and other non-green microalgae). For coastal/estuarine environments, both cyano and chromo rbcL MRNA was predominately confined to the $>5 \mu \mathrm{m}$ size fraction, whereas in offshore oligotrophic environments, the cyano mRNA was associated with smaller cells $(<1 \mu \mathrm{m})$. Similarly, ${ }^{14} \mathrm{C}$ carbon fixation rates and chl a were predominately associated with the $>5 \mu \mathrm{m}$ fraction in coastal/estuarine environments, while in offshore environments, a greater percentage was present in the $<1 \mu \mathrm{m}$ fraction. In profiles through the euphotic zone, cyano rbcL mRNA exhibited maximal values at depths above $65 \mathrm{~m}$ at all stations where the waters were dominated by Synechococcus and Prochlorococcus. In contrast, chromo rbcL mRNA increased with depth from undetectable levels in surface waters to its highest levels at or below the subsurface chlorophyll maximum (SCM, $67 \mathrm{~m}$ or deeper). Carbon fixation rates were generally elevated in both surface waters and around the SCM. The SCM was dominated by chromophytic picoeucaryotes, as detected by HPLC pigment analysis and flow cytometry. Such analyses are consistent with the rbcL gene probe patterns of euphotic zones of of fshore oligotrophic environments. This study demonstrates the utility of group-specific gene probes for examining the expression of carbon fixing genes in phytoplankton and is a first approach to understanding the active phytoplankton community structure and its relationship to the fixation of inorganic carbon in marine environments.
\end{abstract}

KEY WORDS: RubisCO - mRNA · Flow cytometry - HPLC pigments - Natural phytoplankton

\section{INTRODUCTION}

Open ocean phytoplankton communites are taxonomically diverse (Platt \& Li 1986, Tett \& Barton 1995 and references therein) and both spatially and tempo-

\footnotetext{
- Present address: Department of Oceanography, Texas A\&M University, College Station, Texas, 77843, USA

- Addressee for correspondence.

E-mail: jpaul@marine.usf.edu
}

rally heterogeneous. It is now recognized that the majority of open ocean phytoplankton are smaller than those from coastal or estuarine environments, being either ultraphytoplankton $(<5 \mu \mathrm{m})$ or picophytoplankton $(<2 \mu \mathrm{m})$, all of which are adapted to the light, temperature and nutrient conditions of the oligotrophic oceans (Fogg 1995). These ultra- and picophytoplankton communites are comprised of various procaryotic and eucaryotic members (Campbell et al. 1994, Li 1995). The most abundant members of such communi- 
ties appear to be the procaryotic cyanobacteria Synechococcus and Prochlorococcus (Chisholm et al. 1988, Olson et al. 1990a, b, Li 1995). From a carbon content and production standpoint the slightly larger eucaryotic ultraphytoplankton, while less abundant, also seem to contribute significantly to water column carbon metabolism (Li et al. 1993, Li 1994). The varying importance of such groups appears to be partially determined by the physical structure of the water column, with procaryotes being more important under stratified conditions and eucaryotes becoming very abundant under conditions of seasonal mixing, as observed for Red Sea phytoplankton communities (Lindell \& Post 1995). Such conditions have been documented in the North Atlantic where higher latitude communities exposed to greater mixing and lower temperatures are dominated by eucaryotic phytoplankton while communities south of $40^{\circ} \mathrm{N}$ were dominated by Prochlorococcus (Buck et al. 1996).

One of the most consistent global features of the open ocean is the subsurface chlorophyll maximum (SCM), which can occur near the surface during upwelling driven phytoplankton bloom conditions or more commonly near the base of the euphotic zone. The SCM is usually associated with a density discontinuity and resides between the 0.1 and $10 \%$ light level in conditions of a stable water column (Longhurst \& Harrison 1989). However, the mechanisms responsible for its formation and maintenance differ widely. Most of the SCMs are explained by interactions of in situ phytoplankton growth associated with the nitracline (Harrison 1990), hydrography, motility characteristics, and photoadaptation (Cullen 1982). As well as differences in vertical structure of oceanic phytoplankton communities, variations between estuarine, coastal, and offshore phytoplankton communities can be just as dramatic. Estuarine, coastal, and open ocean phytoplankton communities are known to display a range of photosynthetic activities associated with various size fractions (Glover et al. 1986). Carbon fixation and chlorophyll are mainly associated with larger phytoplankton in estuaries, coastal environments, and open ocean communities displaying intense upwelling (Prézelin et al. 1987). However, most open ocean communities do not exist under such conditions and photosynthetic activity (RubisCO activity and carbon fixation) is generally attributed to small cells of the ultraand picophytoplankton.

Several studies have approached the problem of measuring RubisCO gene expression in marine phytoplankton by employing RubisCO specific antibodies (Orellana \& Perry 1992, 1995). We have presented preliminary data on the variation of $r b c L$ gene expression (mRNA) through the euphotic zone for communities of both the offshore Gulf of Mexico (Pichard et al. 1993) and Lake Erie (USA) (Xu \& Tabita 1996). The current study was undertaken to expand on these initial findings by surveying RubisCO gene expression in various size fractions and through the euphotic zone using 1 or 2 RubisCO probes derived from different algal evolutionary lineages. Such a study is fundamental to understanding the size class and spatial patterns of RubisCO gene expression and their relationship to carbon fixation in the various phytoplankton taxa that comprise the marine water column autotrophic community.

\section{MATERIALS AND METHODS}

Phytoplankton culture and DNA isolation. Eucaryotic and procaryotic algae were purchased from the Provasoli-Guillard Culture Collection of Marine Phytoplankton, West Boothbay Harbor, Maine (USA). Eucaryotic phytoplankton Pelagococcus subviridis CCMP1429, Prasinosphaera malaysianus CCMP1536. Skeletonema costatum CCMP775, and Thalassiosira oceanica CCMP1005 were grown in $4 \mathrm{l}$ erlenmeyer flasks containing $2 \mathrm{l}$ of $\mathrm{f} / 2$ media with (for diatoms) or without silica and amended with ampicillin $(100 \mathrm{mg}$ $\mathrm{l}^{-1}$ ) and streptomycin (50 $\mathrm{mg} \mathrm{l}^{-1}$ ) to prevent bacterial growth (Guillard \& Ryther 1962). Cultures were grown at $\sim 23^{\circ} \mathrm{C}$ with illumination provided by cool white fluorescent lights $\left(\sim 150 \mu \mathrm{E} \mathrm{m} \mathrm{m}^{-2} \mathrm{~s}^{-1}\right)$ on a $12 \mathrm{~h}: 12 \mathrm{~h}$ light:dark cycle. The growth media was continuously sparged with $0.22 \mu \mathrm{m}$ filter-sterilized air at $1.51 \mathrm{~min}^{-1}$ using a glass fritted bubbler. Tetraselmis sp. and Isochrysis galbana were provided by Y. Lu (University of South Florida, St. Petersburg, FL, USA) and grown in $500 \mathrm{ml}$ of $\mathrm{f} / 2$ media in $1 \mathrm{l}$ flasks. Cultures were harvested after $14 \mathrm{~d}$ growth by centrifugation at $3832 \times \mathrm{g}$ for 15 min (Sorvall GS-3 rotor; Dupont Co., Wilmington, DE, USA). Cell pellets were washed twice with $1 / 20$ volume of $\mathrm{f} / 2$.

For eucaryotic phytoplankton total DNA was isolated by the method of Chesnick \& Cattolico (1993) for unicellular algae. Total DNA was isolated by resuspending the algal pellet in $7 \mathrm{ml}$ of lysis buffer containing $50 \mathrm{mM}$ Tris, $500 \mathrm{mM}$ EDTA (pH 8.0) and $200 \mu$ l of an aqueous $10 \mathrm{mg} \mathrm{ml}^{-1}$ solution of Proteinase $\mathrm{K}$ for $10 \mathrm{~min}$ at $4^{\circ} \mathrm{C}$. An additional $200 \mu \mathrm{l}$ Proteinase $\mathrm{K}$ was added along with $1 \mathrm{ml}$ of $20 \% \mathrm{~N}$-laurylsarcosine and the mixture incubated at $75^{\circ} \mathrm{C}$ for 5 min. Cell breakage by a French Press was replaced by passage 15 times through a 22 gauge needle using a $10 \mathrm{ml}$ syringe and passage repeated until no intact cells were observed by microscopy. The mixture was then extracted once with phenol:chloroform and then with chloroform and the DNA precipitated overnight at $-40^{\circ} \mathrm{C}$ with $1 / 10$ volume $3 \mathrm{M}$ sodium acetate $\mathrm{pH} 5.0$ and 2 volumes of $100 \%$ ethanol. 
Procaryotic phytoplankton, Prochlorococcus marinus CCMP1377 (Sargasso Sea SS52), Prochlorococcus marinus MED (a gift from B. Palenik, Scripps Institute of Oceanography, Univ. of San Diego, La Jolla, CA, USA), Prochlorococcus sp. Pacific, and Synechococcus sp. CCMP836 (WH8007) were grown in $1 \mathrm{l}$ of media in either a 21 acid washed glass flask (for Synechococcus) or in two 11 acid washed polymethylpentene flasks (for Prochlorococcus) at $20^{\circ} \mathrm{C}$ on a $12 \mathrm{h:} 12 \mathrm{~h}$ light dark cycle for $10 \mathrm{~d}$. lllumination was provided by cool white fluorescent lights at $\sim 20 \mu \mathrm{E} \mathrm{m} \mathrm{m}^{-2} \mathrm{~s}^{-1}$. Synechococcus strains were cultured in SN media (Waterbury \& Willey 1988) and Prochlorococcus strains in $\mathrm{K} / 10$ (-Cu) media (Chisholm et al. 1992). Both media were made with aged ( $>6 \mathrm{mo}$ ) offshore seawater collected from the Gulf of Mexico that was $0.22 \mu \mathrm{m}$ filtered for all procaryotic phytoplankton except the Prochlorococcus sp. Pacific strain, the media for which was made with aged seawater from the Pacific Ocean. Cells were recovered by centrifugation at $3832 \times g$ (Sorvall GS-3 rotor) for $20 \mathrm{~min}$. The cell pellet was resuspended in $1 / 20$ volume culture media and recentrifuged at $7796 \times g$ (Sorvall SS-34 rotor). Cell pellets were stored frozen at $-80^{\circ} \mathrm{C}$ until further processing for DNA. Synechoccoccus $\mathrm{sp}$ PCC6301 was cultured in BG11 (Pichard \& Paul 1991) under the same conditions as for other Synechococcus strains. Synechococcus WH8002 and WH8003 were provided as cell pellets by A. M. Wood (University of Oregon, Eugene, OR, USA). Total DNA from all procaryotic cell peliets was isolated according to the method of Woad \& Townsend (1990) with ultracentrifugation purification omitted. Both extracted procaryotic and eucaryotic phytoplankton DNAs were quanitified by fluorometry using the DNA stain Hoecsht 33258 (Paul \& Myers 1982).

Escherichia coli, Bacillus subtilis, and Saccharomyces cerevisiae DNAs were purchased from Sigma Chemical Co., St. Louis, MO, USA. Purified marine bacteriophage HSIC-3 DNA was provided by C. Kellogg (University of South Florida)

Sampling procedures. Samples were collected during a cruise aboard the RV 'Suncoaster' in September 1993 (see Table 2). Sampling also occurred on cruises aboard the RV 'Pelican' in June 1993 (see Fig. 4) and August 1994 (cf. Table 2, Figs. 5 \& 6) The following core parameters were sampled at all stations: ${ }^{14} \mathrm{C}$ carbon fixation, cyano mRNA and DNA, chl $a$, and autofluorescent and bacterial direct counts. In addition, chromo
mRNA and DNA, HPLC pigment analysis and flow cytometric cell counts were collected at profile stations on the August 1994 research cruise. Seawater samples were collected in mid-morning, between 09:30 and 12:00 h, at stations shown in Fig. 1. Surface $<5 \mathrm{~m}$ depth) seawater samples for size fractionation studies were collected by use of a Rule 1800 submersible pump (Glover et al. 1986, Prézelin et al. 1989), lowered over the side of the research vessel, and used to fill 201 acid-washed polycarbonate carboys. Size fractionation was performed by filtration through $5 \mu \mathrm{m}$, $1 \mu \mathrm{m}$, and $0.6 \mu \mathrm{m}$ Nuclepore polycarbonate filters under reduced vacuum $(<15 \mathrm{~mm} \mathrm{Hg}$ ). The phytoplankton biomass in each filtrate was then collected onto filters for various analyses as described in Pichard et al. (1996). All profiling through the euphotic zone was accomplished by sampling with 5 and 201 niskin bottles. Water from each depth was then transferred to 201 acid-washed polycarbonate carboys covered with black plastic bags to avoid light shock. Temperature, salinity, in situ fluorescence, and oxygen partial pressure were determined using the onboard Seabird CTD, polarographic $\mathrm{O}_{2}$ sensor and blue light fluorometer on the rosette sampler.

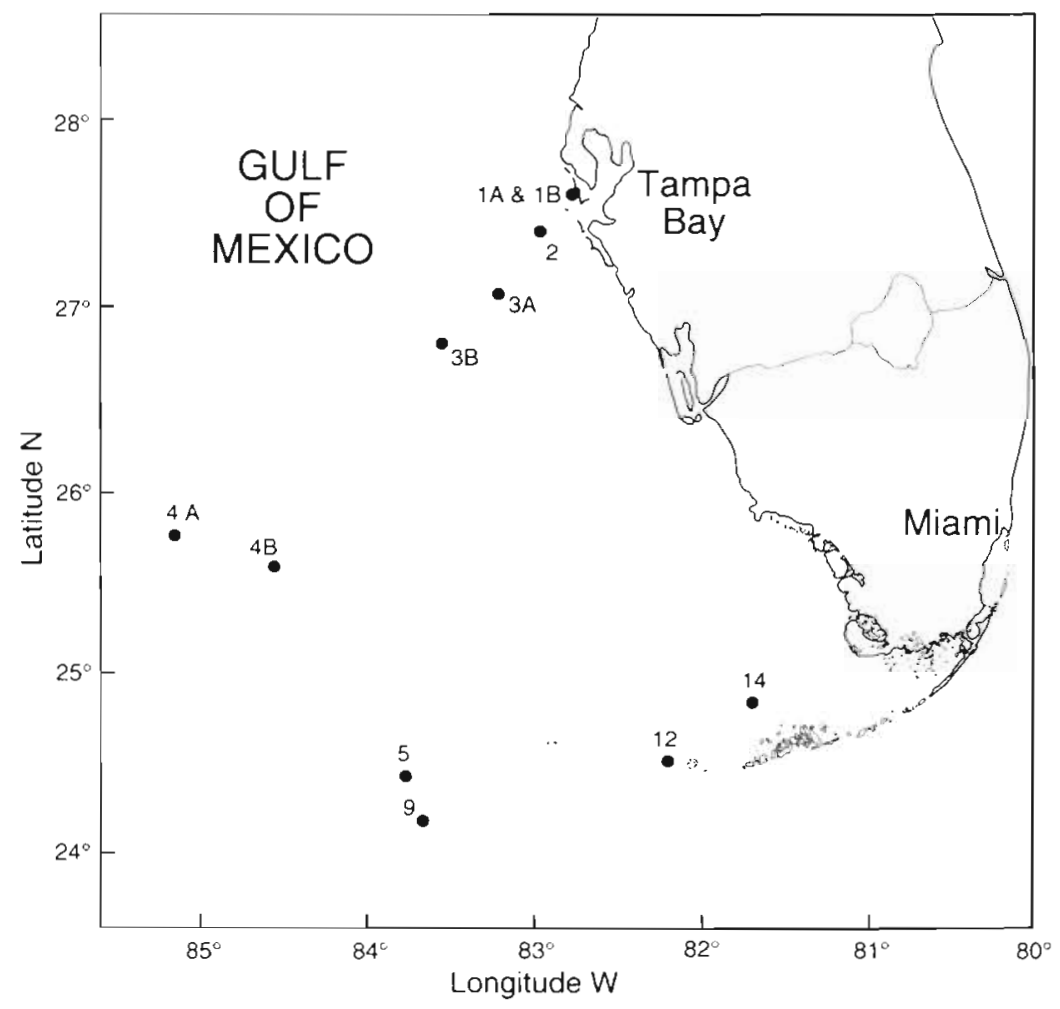

Fig. 1 Location of stations sampled for RubisCO (cyano and chromo) $r b c L$ mRNA, ${ }^{14} \mathrm{C}$ carbon fixation, and other parameters. Stns $1 \mathrm{~A}, \mathrm{~B}, 2,3 \mathrm{~A}, \mathrm{~B}$, $4 \mathrm{~A}, 12$, and 14 were the locations of the size fractionated surface seawater studies. Stns $4 B, 5$, and 9 were the locations of profiles of gene expression through the euphotic zone 
Rubisco mRNA and DNA analysis. The extraction of $r b c L$ mRNA was accomplished by a combination of guanidinium-isocitrate-phenol (GIPS) extraction coupled with bead-beating as previously described (Pichard et al. 1993, Paul \& Pichard 1995). rbcL DNA extractions were performed by boiling lysis as in Pichard et al. (1993) and Paul \& Pichard (1995). Both RNA and DNA blots were prepared as previously described (Pichard et al. 1993). Both sets of blots were probed only with the $2 \mathrm{rbcL}$ probes (Fig. 2) derived from 2 major evolutionary lineages of RubisCO at Stns $1 B, 4 A, B, 9$, and 12. At all other stations sampled both blots were probed only with the cyano probe. Hybridization conditions used were those described in Pichard \& Paul $(1991,1993)$. An rbcL probe from Synechococcus sp. PCC 6301 was used to detect chlorophyte and cyanobacterial rbcL mRNA and DNA while an $r b c L$ probe from the diatom Cylindrotheca sp. was used to detect chromophyte rbcL mRNA and DNA. These genes share only $60.9 \%$ sequence identity over the entire gene (1416 bp for Synechococcus; Genbank accession \#K00486, and 1473 bp for Cylindrotheca; Genbank accession \#M59080), as determined using the NALIGN program of PCGENE release 15.0 (Intelligenetics Inc., Mountain View, CA). Sample RNA and DNA signals were compared to signals obtained from standard curves of in vitro synthesized cyano and chromo $r b c L$ mRNA and DNA by use of a radioanalytic imaging system previously described (Pichard \& Paul 1993). The limits of detection for such an analysis are in the range of 0.005 to $0.001 \mathrm{ng}$ (Pichard \& Paul 1993 Pichard et al. 1993).

Chl a determinations and cell counts. Samples for chl a were collected by filtration onto GF/F filters and stored frozen until analysis. Chl a concentrations in methanol extracts were determined fluorometrically (Holm-Hansen \& Riemann 1978). Autofluorescent cell counts (yellow/orange-fluorescing: Synechococcus and chl a-fluorescing; red-fluorescing cells) were performed by an adaptation of the Vernet method (Vernet et al. 1990) and bacterial direct counts were performed by DAPI staining (Paul \& Myers 1982) except where determined by flow cytometric methods.

Flow cytometry analysis. Samples for flow cytometric determination of the phytoplankton community and heterotrophic bacteria were collected at Stns $4 \mathrm{~B}$ and 9 fixed with paraformaldehyde $10.2 \%$ final concentration), frozen in liquid nitrogen, and maintained at $-80^{\circ} \mathrm{C}$ until analyzed. Bacteria were stained with Hoechst 33342. Samples were analyzed as described in Campbell et al. (1994).

Phytoplankton pigment analysis. Algal pigments (13) analyzed in this study and their taxonomic affiliations are listed in Table 1 . For pigment analyses, $\sim 4$ of water was filtered under low vacuum through Whatman GF/F filters in duplicate and the filters immediately frozen and stored in liquid nitrogen for transfer to the laboratory. Samples were then stored at $-80^{\circ} \mathrm{C}$ until analysis. Filters were extracted in 100\% acetone and the extracts analyzed by high performance liquid

Table 1. Major phytoplankton pigments utilized for analysis of the taxonomic composition of natural phytoplankton communities Table based on data from Wright et al. (1991), Millie et al. (1993), and Andersen et al. (1996). Groups shown in bold type are taxonomically diagnostic. 'Members of the chromophyte assemblage

\begin{tabular}{|ll}
\hline Pigment & Phytoplankton taxonomic group \\
\hline Chlorophylls & \\
Chl $a 1$ & All taxa except Prochlorophytes \\
Chl $a 2$ & Prochlorophytes only \\
Chl $b 1$ & Chlorophytes, Prasinophytes, Prochlorophytes \\
Chl $b 2$ & Prochlorophytes only \\
Chl $c 1 \& c 2$ & Diatoms, Chrysophytes, Prymnesiophytes, Raphidophytes, Pelagophytes, Cryptophytes, \\
& Xanthophytes, Dinoflagellates \\
Carotenoids & \\
Lutein & Chlorophytes, some Prasinophytes \\
9'-Cis-neoxanthin & Chlorophytes, Prasinophytes \\
Violaxanthin & Chlorophytes, Prasinophytes, Chrysophytes \\
Prasinoxanthin & Some Prasinophytes \\
Fucoxanthin & Diatoms, Chrysophytes, Prymnesiophytes, Pelagophytes \\
Diadinoxanthin & Diatoms, Prymnesiophytes, Pelagophytes, Dinoflagellates \\
Diatoxanthin & Diatoms, Prymnesiophytes, Pelagophytes, Dinoflagellates \\
$19^{\prime}-$ Butanoyloxyfucoxanthin & Prymnesiophytes, Pelagophytes, Raphidophytes, a few Dinoflagellates \\
19 '-Hexanoyloxyfucoxanthin & Prymnesiophytes, Chrysophytes, a few Dinoflagellates \\
Dinoxanthin & Prymnesiophytes, Dinoflagellates \\
Peridinin & Most photosynthetic Dinoflagellates \\
Zeaxanthin & Cryptophytes, Cyanophytes, Prasinophytes, Prochlorophytes \\
Alloxanthin & Cryptophytes \\
\hline
\end{tabular}


Synechococcus sp. PCC6301 rbcl (Cyano)

RNA polymerase promoters

Muttiple cloning site

Cloned gene
Fig. 2. Plasmids pLC1 and pRLD1 used in this study to produce antisense (AS) RNA gene probes for different evolutionary types of $\mathrm{rbcL}$ (RubisCO). Both the rbcL genes from Synechococcus sp. PCC6301 (cyano; cyanobacterial and chlorophyte type) and Cylindrothecasp. (chromo; chromophyte algal type) were subcloned into riboprobe pGEM3Z vectors to produce the constructs shown. Specificity of the probes to a variety of phytoplankton taxa is shown in Fig. 3

chromatography (HPLC) using a Hewlett Packard model 1090 HPLC equipped with a C18 column and diode array detector as in Millie et al. (1995). Reverse phase and forward phase HPLC pigment analysis was performed in the laboratory of $G$. J Kirkpatrick, Mote Marine Laboratory, Sarasota, FL.

${ }^{14} \mathrm{C}$ carbon fixation. All ${ }^{14} \mathrm{C}$ assimilation studies were performed essentially the same as in Pichard et al. (1993) with the following modifications for euphotic zone vertical profile studies. On-deck incubations were performed with reduced natural irradiance that was adjusted to resemble the spectral features of the underwater light field (deep blue penetrating wavelengths) through use of a combination of neutral density screening and blue and blue-green wavelength passing colored acetate filters (Jitts 1963, Prézelin et al. 1989, Prézelin \& Glover 1991). Irradiance intensity was adjusted to the natural intensity existing at each sample depth as measured using a Li-190SA and Li-192SA surface and underwater PAR sensors (Li-Cor Inc., Lincoln, NE, USA). Temperature regulation was provided by running surface seawater.

Data analysis. Regression analysis (Zar 1984) was used to determine sample $r b c L$ mRNA and DNA concentrations from standard curves. Correlation analyses (simple and multiple) were performed using Statgraphics Plus for Windows version 1.0 (Manuagistics, Inc., Rockville, MD, USA). Data was log transformed prior to analysis, where necessary, to meet the conditions of homogeneity of variances.
Cylindrotheca sp. rbcl (Chromo)
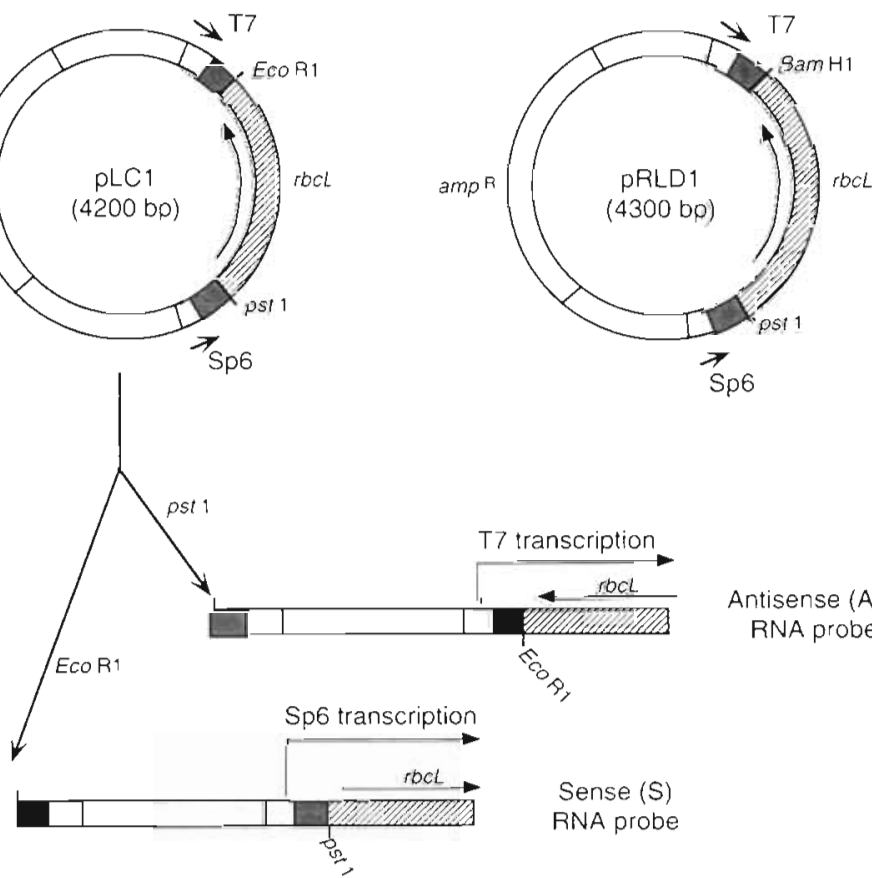

Antisense (AS) RNA probe

\section{RESULTS}

The rbcL gene probes from Synechococcus PCC6301 and Cylindrotheca sp. were tested against a variety of phytoplankton DNA targets at the hybridization conditions used for natural samples (Frischer et al. 1990) as shown in Fig. 3. The cyano gene probe hybridized to DNA from several marine Prochlorococcus sp., Synechococcus sp., and prasinophyte algae (Tetraselmis sp. and Prasinosphaera malaysianus) but did not yield a detectable signal with any of the chromophyte algae targets. Conversely, the chromo gene probe hybridized with several diatoms (Cylindrotheca sp., Skeletonema costatum, and Thalassiosira oceanica), a pelagophyte alga (Pelagococcus subviridis), and a prymnesiophyte alga (Isochrysis galbana) but not with any of the prochlorophytes, cyanobacteria or prasinophytes. Neither gene probe hybridized non-specifically with DNA from bacteria (Bacillus subtilis and Escherichia coli), a marine bacteriophage (HSIC-3), or yeast (Saccharomyces cerevisiae).

\section{Size fraction experiments}

Surface water natural phytoplankton communities were sampled from $<5 \mathrm{~m}$ depth at a variety of stations shown in Fig. 1. Size fraction data for parameters measured appear in Table 2. At a coastal/estuarine station (Stn 1A, B, entrance to Tampa Bay) cyano rbcL mRNA, 


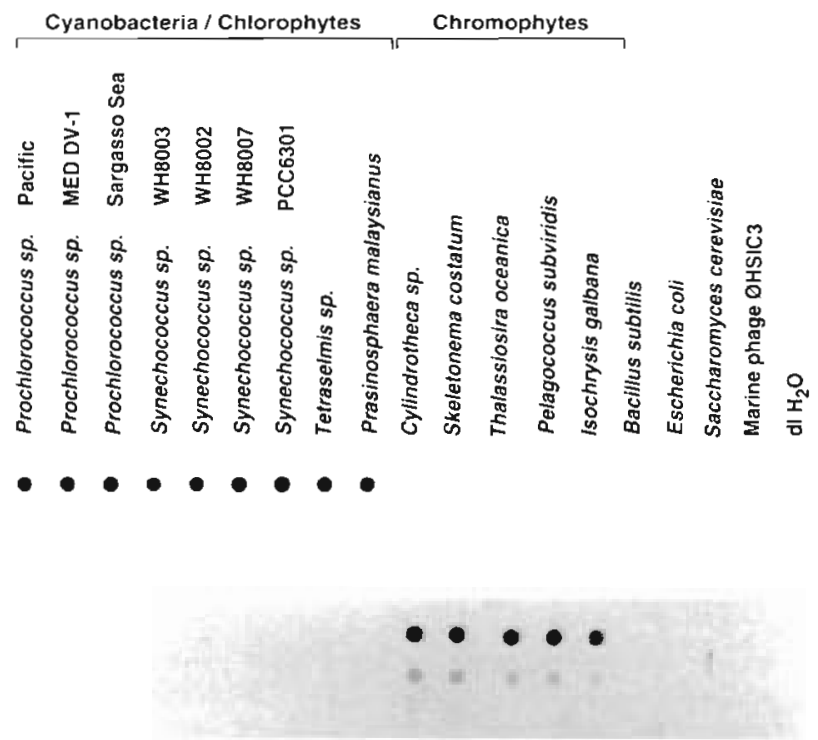

Fig. 3. Specificity of the cyano and chromo rbcL gene probes for a variety of target phytoplankton $r b c L$ genes. Probes were hybridized to total DNA preparations from phytoplankton, as mentioned in the text, under the hybridization conditions used to detect rbcL DNA in natural phytoplankton communities Bacterial, yeast, and bacteriophage DNA and sterile delonized water were used as negative controls

carbon fixation, and chl a were predominately found in the largest size fraction ( $>5 \mu \mathrm{m}$ ). Cyano rbcL DNA was approximately equally partitioned between the $1-5 \mu \mathrm{m}$ and $<1 \mu \mathrm{m}$ fractions, with $10 \%$ of cyano DNA in the $>5 \mu \mathrm{m}$ fraction. At Stn $1 \mathrm{~B}$, chromo rbcL mRNA was all found in the $>1 \mu \mathrm{m}$ fraction while chromo $r b c L$ DNA was mainly in the $<1 \mu \mathrm{m}$ fraction. Red-fluorescing cells were mainly $>1 \mu \mathrm{m}$ in size while Synechococcus were either confined to the $<1 \mu \mathrm{m}$ size class (Stn 1B) or equally distributed between $<1$ and $>5 \mu \mathrm{m}$ size fractions, possibly due to aggregate formation.

At Stn 2, a coastal station, cyano rbcL mRNA was approximately equally partitioned between the $>5$ and $<1 \mu \mathrm{m}$ fractions. This pattern did not repeat itself for carbon fixation rates or chl a where the majority of carbon fixation was shifted towards the smaller size fractions ( $44 \%<1 \mu \mathrm{m}$ and $31 \%$ in the $1-5 \mu \mathrm{m})$ and the majority of chl a appeared in the $>5 \mu \mathrm{m}(45 \%)$ and $<1 \mu \mathrm{m}(32 \%)$ fractions. The majority of the cyano DNA $(70 \%)$ passed through the $1 \mu \mathrm{m}$ filter In this case, expression on a DNA (template) basis displayed a greater proportion of RNA per DNA in the $>5 \mu \mathrm{m}$ size fraction (mRNA:DNA $=87.5)$ and less in smaller size fractions $1-5 \mu \mathrm{m}$ (mRNA:DNA $=10.3$ ) and $<1 \mu \mathrm{m}$ (mRNA: DNA $=14.3)$. The majority $(63 \%)$ of red cells were $>5 \mu \mathrm{m}$ while most Synechococcus were in the smaller size fractions of $1-5 \mu \mathrm{m}(31 \%)$ and $<1 \mu \mathrm{m}(58 \%)$.

Other coastal stations sampled included a subtropical mangrove-fringed lagoon (Marquesas; Stn 12) and a station located on the far edge of southwestern Florida Bay (Stn 14). At Stn 12 cyano $r b c L$ mRNA was found equally in both the $>5$ and $<1 \mu \mathrm{m}$ size fractions while at Stn 14 twice as much cyano mRNA was $<1 \mu \mathrm{m}$. Large amounts of chromo rbcL mRNA were found in the $>5 \mu \mathrm{m}$ fraction, at $\operatorname{Stn} 12$, while small quantities of DNA (both cyano and chromo) were detected in all size fractions. Thus the cyano and chromo mRNA:DNA ratios indicate that the majority of RubisCO gene expression at Stn 12 is contained in $>5 \mu \mathrm{m}$ cells (cyano mRNA:DNA $=140$ ), as might be expected in a subtropical lagoon environment. Similarly, the cyano mRNA:DNA ratios at $\operatorname{Stn} 14$ also indicate the $>5 \mu \mathrm{m}$ fraction is the most active (mRNA:DNA = 105) even though twice as much mRNA is in the $<1 \mu \mathrm{m}$ fraction. For Stn 12 carbon fixation and chl a reflect a similar size distribution as seen at Stn $1 \mathrm{~A} / 1 \mathrm{~B}$ since the overwhelming majority of of both carbon fixation and chl $a$ were in the $>5 \mu \mathrm{m}$ fraction 87 and $79 \%$, respectively). Alternatively, the size distribution of carbon fixation at $\operatorname{Stn} 14$ resembled that found at Stn $3 \mathrm{~A}$ (an offshore environment) where carbon fixation is shifted towards phytoplankton of smaller size $(74 \%<1 \mu \mathrm{m})$. Stn 14 chl a size distribution patterns resembled those at Stn 2. At both stations (12 and 14) red cells were mainly present in the $1-5 \mu \mathrm{m}$ size fraction while Synechococcus were mainly $<1 \mu \mathrm{m}$.

At Stns $3 \mathrm{~A}$ and $3 \mathrm{~B}$, offshore oligotrophic environments, the majority of the cyano rbcL mRNA, carbon fixation, and $c h l$ a appears in the $<1 \mu \mathrm{m}$ size fraction $(86,51$, and $56 \%$ for $3 \mathrm{~A}$, and 84,55 , and $69 \%$ for $3 \mathrm{~B}$, respectively). The majority of the red cells were 1-5 $\mu \mathrm{m}$ in size at $\operatorname{Stn} 3 \mathrm{~A}$ and $>5 \mu \mathrm{m}$ at $\mathrm{Stn} 3 \mathrm{~B}$. Few red cells were observed in the $<1 \mu \mathrm{m}$ fraction at either station. At Stn $3 \mathrm{~A}$ the majority of Synechococcus were $<1 \mu \mathrm{m}$ while at $\mathrm{Stn} 3 \mathrm{~B}$ a larger portion were $>5 \mu \mathrm{m}$. Cyano rbcL DNA was found equally distributed between the $<1 \mu \mathrm{m}$ and $>5 \mu \mathrm{m}$ at Stn $3 \mathrm{~A}$ and distributed amongst all 3 size classes examined at $\operatorname{Stn} 3 \mathrm{~B}$. At both stations the majority of the activity is contained in the $<1 \mu \mathrm{m}$ fraction (mRNA: DNA ranging from 27.6 to 32).

Stn 4A, another offshore oligotrophic environment, largely reflects the size fraction data for Stn $3 \mathrm{~A}$ except that an additional size class, $<0.6 \mu \mathrm{m}$, was examined. Nearly $100 \%$ of the cyano rbcL mRNA signal apparently originated from the smallest size class, $<0.6 \mu \mathrm{m}$. Carbon fixation and chl a were approximately equally 


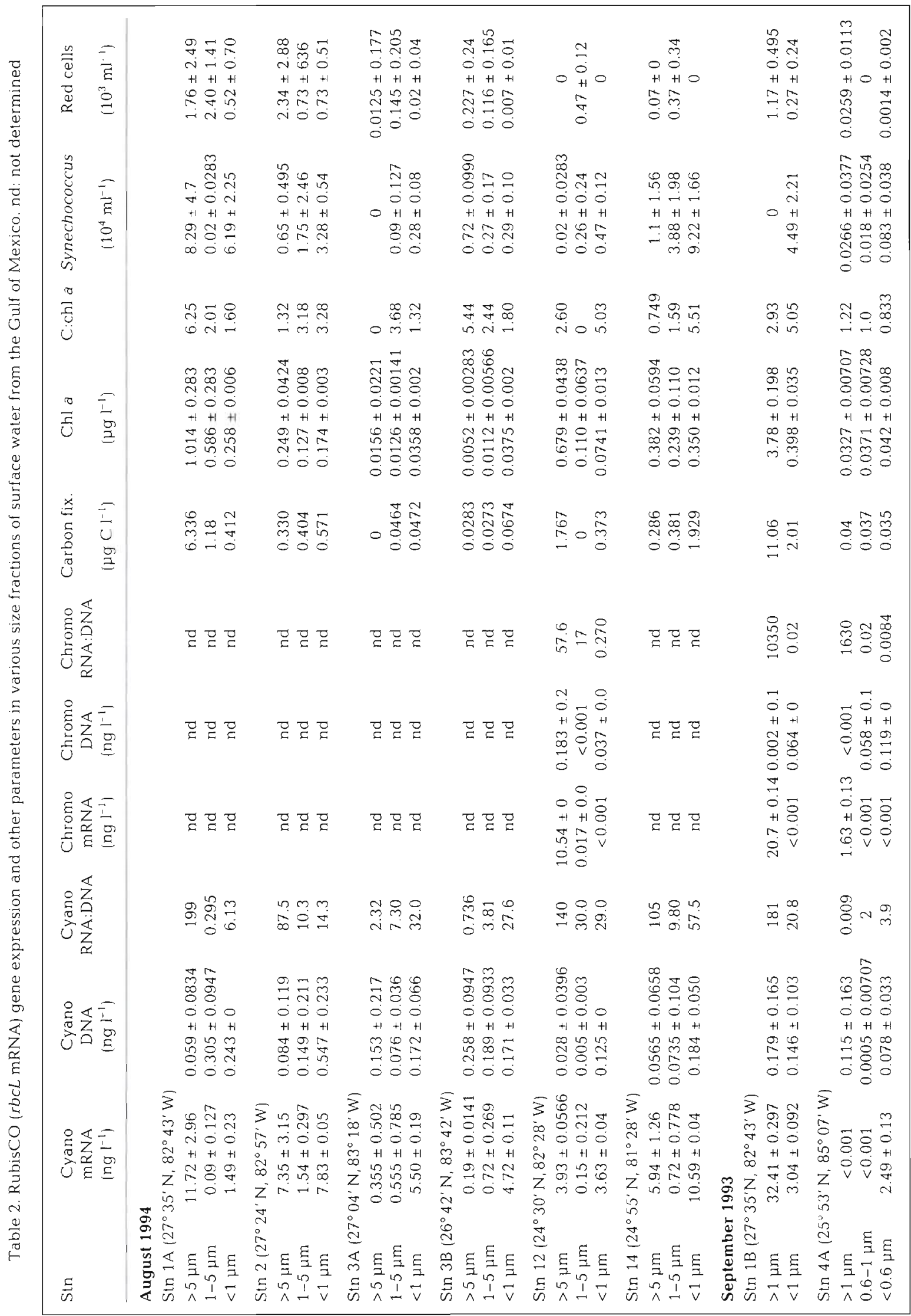


distributed amongst the 3 size fractions. Cyano DNA was approximately equally partitioned in $<0.6 \mu \mathrm{m}$ and $>1 \mu \mathrm{m}$ size fractions. All chromo rbcL mRNA was $>1 \mu \mathrm{m}$ while all of the detected chromo rbcL DNA was contained in 0.6 to $1 \mu \mathrm{m}$ and $<0.6 \mu \mathrm{m}$ size fractions. Synechococcus were found in all 3 size classes but the majority was contained in the $<0.6 \mu \mathrm{m}$. The majority of red cells occupied the $>1 \mu \mathrm{m}$ fraction.

Correlation analysis of the size fraction data using a linear model yielded a significant relationship between rates of carbon fixation and cyano rbcl mRNA ( $\mathrm{r}=$ 0.633, $p=0.0015$ ). The same type of analysis between carbon fixation and chromo $r b c L$ mRNA or total $r b c L$ mRNA (cyano + chromo) generated relationships of lower confidence $(r=0.540, p=0.211$ and $r=0.670, p=$ 0.100 , respectively). A stepwise multiple correlation analysis with carbon fixation as the dependent variable yielded a model in which variations in carbon fixation were related to variations in chla, cyano $r b c L$ mRNA and chromo rbcL mRNA concentrations. The cyano $r b c L$ mRNA and chromo rbcL mRNA exhibited the highest correlations with Synechococcus concentrations $(\mathrm{r}=0.614, \mathrm{p}=0.0023)$ and with chl $a(\mathrm{r}=0.822$, $\mathrm{p}=0.023$ ), respectively.

\section{Depth distribution of gene expression}

rbcL gene expression, and other parameters were examined in profiles through the euphotic zone at 3 of fshore oligotrophic stations in the Gulf of Mexico. At Stn 5 cyano rbcL mRNA increased with depth (Fig. 4) from a surface value of $5 \mathrm{ng} \mathrm{l}^{-1}$ to a maximum of $30 \mathrm{ng}$ $\mathrm{l}^{-1}$ at $65 \mathrm{~m}$, declining rapidly over the next $15 \mathrm{~m}$ to undetectable limits below $100 \mathrm{~m}$. A subsurface maximum in carbon fixation was found $15 \mathrm{~m}$ deeper than the peak in cyano $r b c L$ mRNA. This peak in carbon fixation was coincident with the subsurface chlorophyll maximum (SCM) and the maximal abundance in red cells. The subsurface peak in cyano rbcL mRNA appeared most associated with the small subsurface peak in Synechococcus and a slight elevation in cyano rbcL DNA. This peak in cyano mRNA and Synechococcus abundance was also the depth of the maximum dissolved oxygen concentration suggesting that the Synechococcus population was undergoing vigorous photosynthesis.

At Stns $4 \mathrm{~B}$ and $9, r b c L$ gene expression was monitored using both the cyano and chromo gene probes. At Stn $4 \mathrm{~B}$ (Fig. 5), cyano rbcL mRNA was most abun-
A)

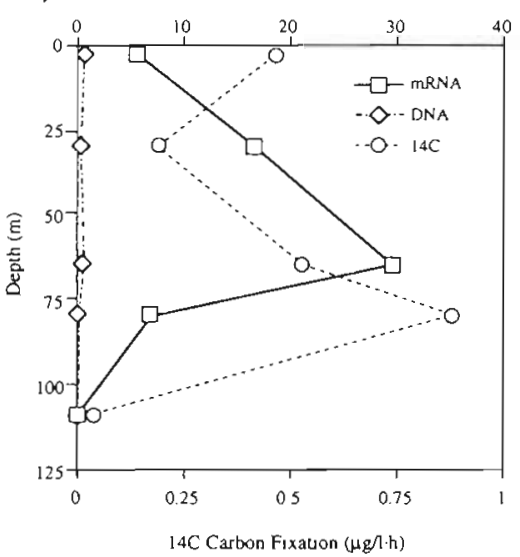

C)

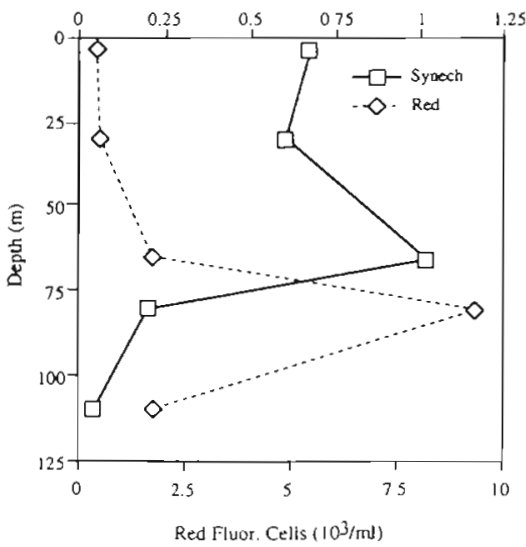

B)

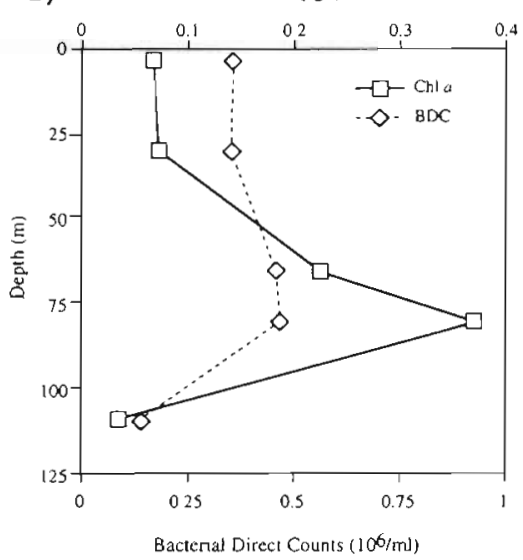

D)

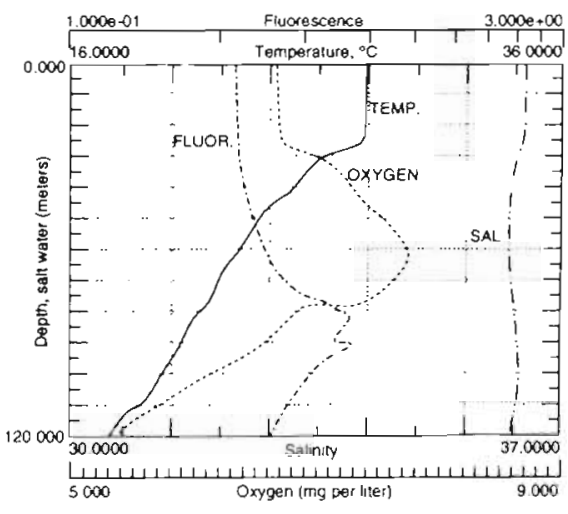

Fig. 4. Vertical profiles of cyano rbcL mRNA, ${ }^{14} \mathrm{C}$ carbon fixation, and other measured parameters at offshore Gulf of Mexico Stn 5 (June 1993). (A) Cyano rbcL mRNA, DNA, and ${ }^{14} \mathrm{C}$ fixation; (B) chl a and bacterial direct counts; (C) autofluorescent cell abundance; (D) CTD measurements of temperature, salinity, in situ fluoresence, and oxygen 

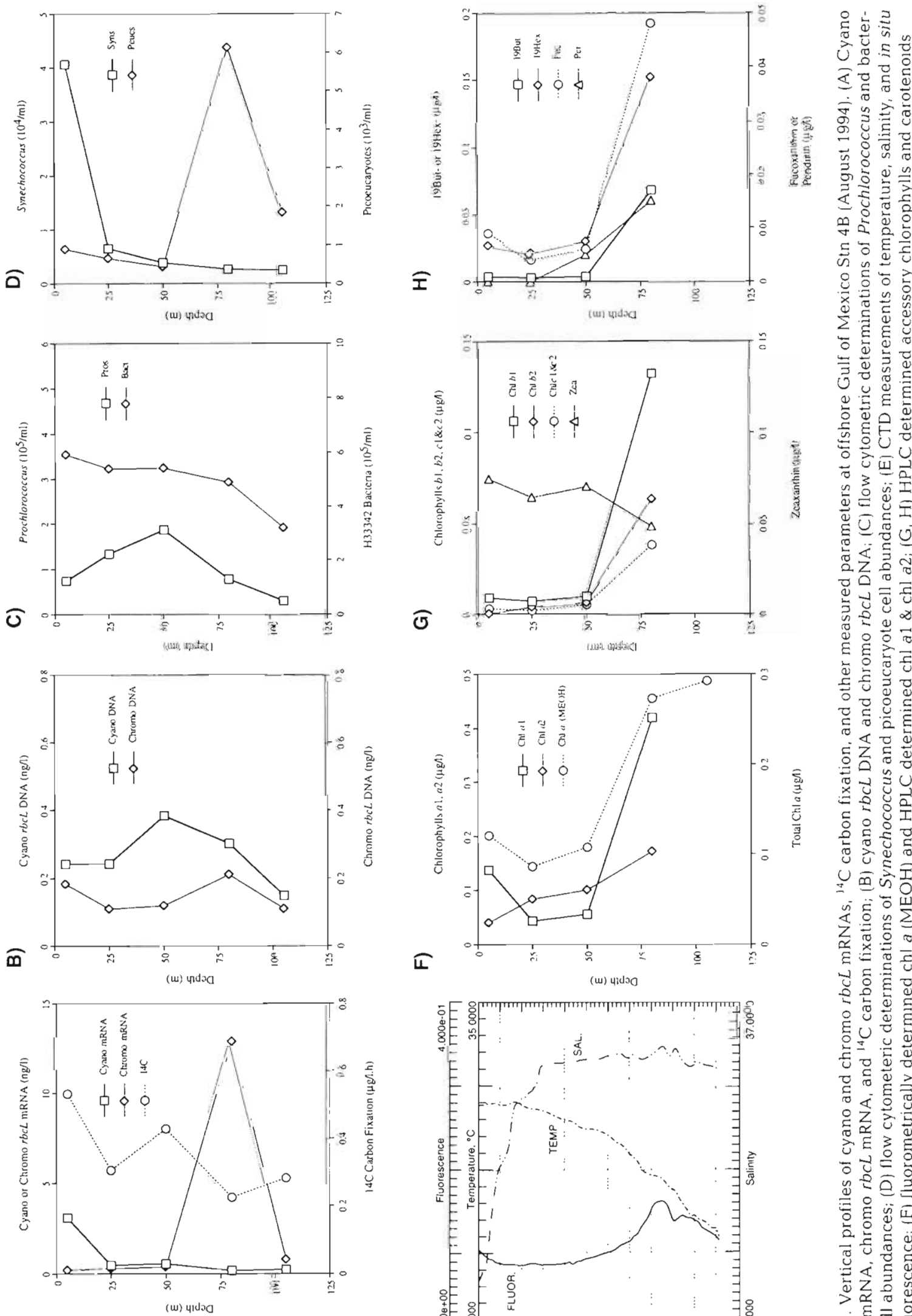

$\widehat{\varangle}$
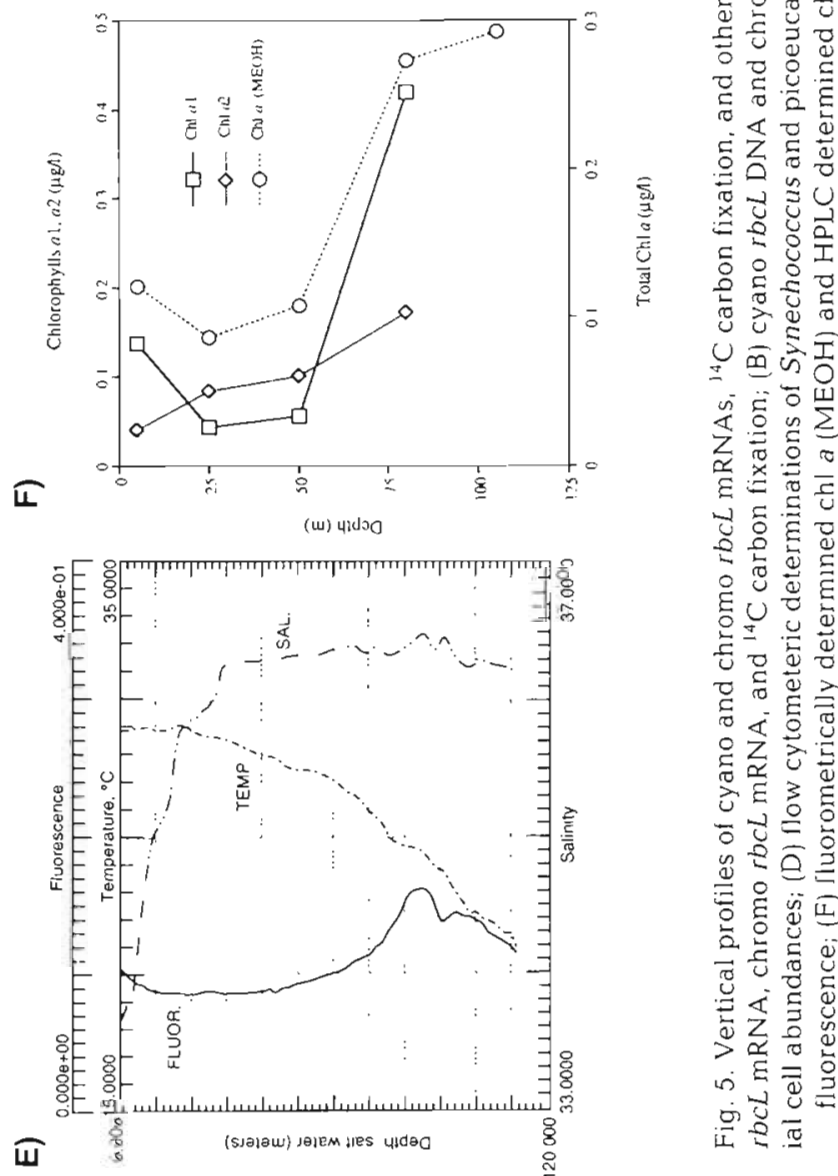
dant in surface waters and declined with depth. Maximal values for carbon fixation were also observed in surface waters at this station although a smaller subsurface peak was also present at $50 \mathrm{~m}$ (Fig. 5A). Conversely, chromo $r b c L$ mRNA displayed maximal values deep in the water column $(80 \mathrm{~m})$ coincident with the SCM. Synechococcus were most abundant in surface waters, Prochlorococcus at mid-depth $(50 \mathrm{~m})$, and picoeucaryotes deep in the euphotic zone at $80 \mathrm{~m}$ (Fig. 5C, D). Both cyano and chromo rbcL DNA (Fig. 5B) displayed little change from surface to $115 \mathrm{~m}$. The phytoplankton taxonomic composition at Stn $4 \mathrm{~B}$ was examined using signature pigments as markers of various phytoplankton taxa (listed in Table 1). The total chl a field was partitioned into both monovinyl chlorophyll (chl a1) and divinyl chlorophyll (chl a2) as shown in Fig. 5F. Maximum concentrations of chl a1 were present at the SCM although there was also a pronounced peak at the surface. These 2 peaks are likely the result of the distribution of both Synechococcus and picoeucaryote cells. Prochlorococcus markers (chl a2 \& chl b2) were most abundant at the $80 \mathrm{~m}$ depth. (SCM) although these pigments and Prochlorococcus were readily detected throughout the water column. Zeaxanthin (cyanobacteria) was found at highest concentration at the surface and decreased slightly with depth. Pigment markers for various eucaryotic phytoplankton (accessory chlorophylls and carotenoids; Fig. 5G, H) were also present in high concentrations at the SCM. 19'-Butanoyloxyfucoxanthin (pelagophytes), 19'-hexanoyloxyfucoxanthin (prymnesiophytes) and fucoxanthin (diatoms) were also elevated at the SCM suggesting the presence of these classes of chromophytic phytoplankton in this assemblage. The pigments peridinin (Fig. $5 \mathrm{H}$ ) and dinoxanthin (data not shown) were also present in the SCM, indicative of dinoflagellates, but absent in surface waters. True chlorophytes were also not abundant at this station based on the absence of lutein (data not shown). While prasinoxanthin (prasinoxanthin is not present in all prasinophytes) was not detected in any sample, the pigment $9^{\prime}$-cis-neoxanthin was present at $80 \mathrm{~m}(0.007 \mu \mathrm{g}$ $1^{-1}$ ), which suggests that prasinophyte algae were probably responsible for the increased levels of chl $b 1$ at $80 \mathrm{~m}$. A small amount of alloxanthin $\left(0.005 \mu \mathrm{g} \mathrm{l}^{-1}\right)$ was also detected at the SCM indicating cryptophyte algae might also contribute to the SCM community

Fig. 6 shows the results of a similar analysis through the euphotic zone at Stn 9. Cyano rbcL mRNA was maximal at $25 \mathrm{~m}$ and declined with depth while chromo $r b c L$ mRNA was undetectable in surface waters and reached maximum levels at the SCM and deeper (Fig 6A). Carbon fixation rates were maximal in surface waters and declined with depth with a small subsurface peak at the SCM $(70 \mathrm{~m})$. As at Stn 4, Syne- chococcus were maximal in surface waters with a small peak at the SCM, while picoeucaryotes were most abundant at the SCM (Fig. 6D).

Prochlorococcus were present throughout the euphotic zone with maximum abundance at $50 \mathrm{~m}$, a $\sim 20$-fold greater abundance than Synechococcus. Unlike any other station, both cyano and chromo rbcL DNA varied by $\sim 4$-fold over the water column with cyano $r b c L$ DNA levels being highest in surface waters (above $25 \mathrm{~m}$ ) and declining with depth, and chromo $r b c L$ DNA reaching maximum levels at $50 \mathrm{~m}$ and declining with depth.

HPLC pigment analysis was also performed on samples from Stn 9 for assessing the composition of the phytoplankton community. Most of the pigments had maxima coincident with the SCM. The only exception to this was the increase in zeaxanthin in the upper water column and chl $b 2$ which reached a maximum concentration at the deepest depth sampled of $115 \mathrm{~m}$ (Fig. 6G). Dinoflagellates were apparently absent or at dramatically reduced concentrations than at Stn $4 \mathrm{~B}$, as peridinin was not detected. Again pelagophytes, prymnesiophytes, diatoms and chrysophytes were present as part of the SCM community as 19'-butanoyloxyfucoxanthin (19'-but-fuc), 19'-hexanoyloxyfucoxanthin (19'-hex-fuc), and fucoxanthin (Fig. 6H) were present in higher concentrations than elsewhere in the water column. Similar to Stn 4B, undetectable lutein and 9'-cis-neoxanthin indicated that true chlorophyte algae were not present but that prasinophytes were responsible for the chl b1 at depth. Alloxanthin was only detected at the SCM $\left(0.007 \mu \mathrm{g} \mathrm{l}^{-1}\right)$.

Linear correlation of the profile data set yielded a significant relationship between carbon fixation and the concentration of Synechococcus ( $r=0.828, p=$ 0.0031 ). Cyano $r b c L$ mRNA levels also correlated with Synechococcus but with reduced confidence $(r=0.612$, $\mathrm{p}=0.0601$ ). The variation in chromo $r b c L$ mRNA was highly correlated with red-fluorescing picoeucaryote concentrations $(r=0.791, p=0.0065)$. The picoeucaryote phytoplankton can be inferred to be composed of the chromophyte algae as correlations with chromophyte type pigments (fucoxanthin, 19'-hex-fuc, 19'but-fuc, and chl $c 1 \&$ \&2) displayed correlation coefficients ranging from $r=0.762$ to $r=0.939$, all at $a$ confidence level of $p<0.01$. However, a stepwise multiple correlation of carbon fixation against all measured parameters failed to find a single variable that could completely explain the variation in carbon fixation rates.

A multiple correlation analysis of the entire data set (profiles and whole numbers from the size fraction studies) with carbon fixation as the dependent variable yielded a model in which variation in carbon fixation rates could be explained by variations in the 3 parame- 

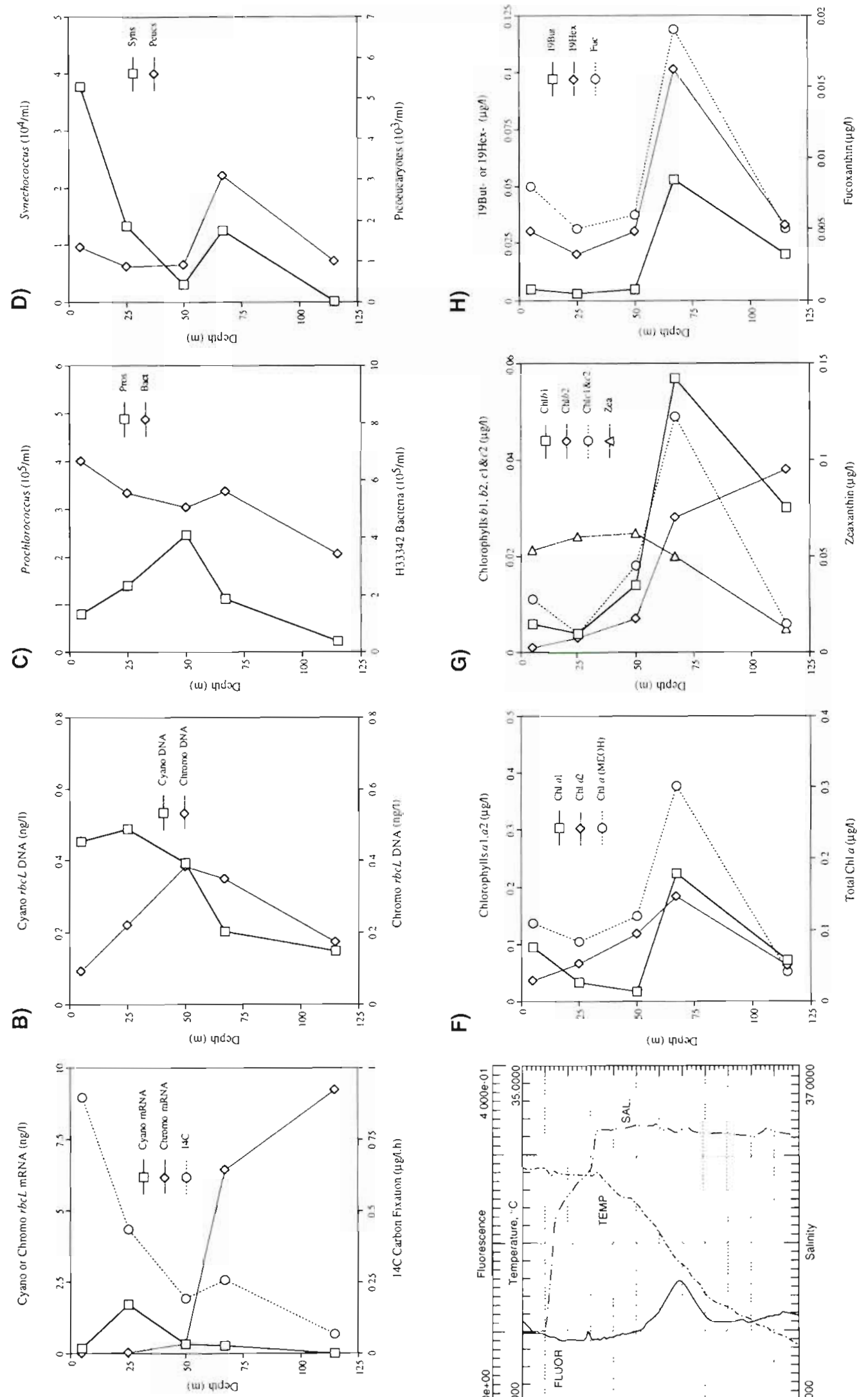

$\widehat{\varangle}$
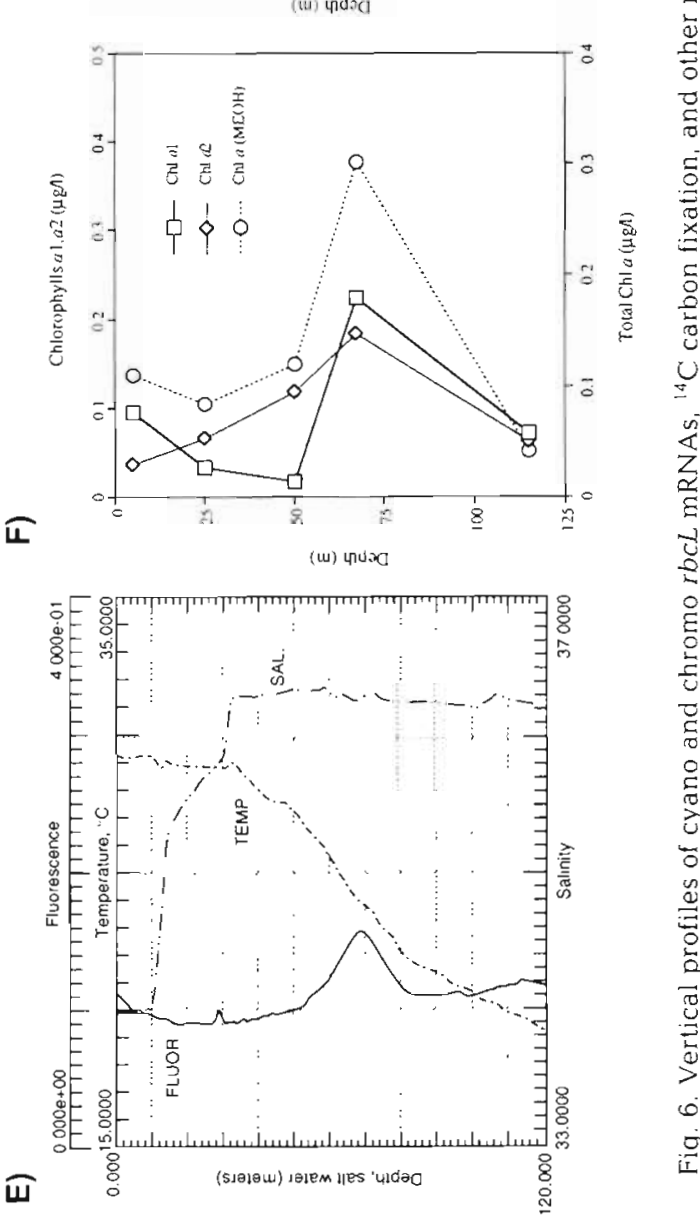
ters, chl $a$, cyano rbcL mRNA, and chromo rbcL mRNA. Cyano rbcL mRNA was most dependent on the concentration of Synechococcus ( $r=0.903, p=0.0027$ ) and chromo $r b c L$ mRNA correlated most with red-fluorescent cells $(r=0.902, p=0.0009)$.

\section{DISCUSSION}

Marine phytoplankton communities are made up of organisms of various size classes and various taxa. Proceeding from coastal/estuarine environments to the open ocean, the relative abundance of specific phytoplankton taxa changes from larger eucaryotic cells such as diatoms to small procaryotes such as Synechococcus and Prochlorococcus. Using 2 different rbcl gene probes we have found that in coastal/estuarine surface waters both chlorophytic/cyanobacterial and chromophytic gene expression were associated with larger phytoplankton (>5 $\mu \mathrm{m}$ in size). In offshore surface waters cyano $r b c L$ expression was found primarily in cells $<1 \mu \mathrm{m}$ in size and occasionally in the 1-5 $\mu \mathrm{m}$ fraction. This trend is generally reflected in other autotrophic parameters such as ${ }^{14} \mathrm{C}$ carbon fixation and chl a. The relatively low amount of chromo $r b c L$ probe hybridization in size fractionation studies of open ocean surface waters may be a reflection of the vertical structure of the euphotic zone phytoplankton communities. In offshore environments chromophyte algae were at greater abundance deep in the euphotic zone as demonstrated by HPLC pigment signatures as well as chromo rbcL probe hybridization patterns. Therefore, while the chromo probe detected a small amount of $r b c L$ mRNA in surface waters, it appears that it is more aptly suited to studying such populations in coastal/estuarine surface water phytoplankton communities or offshore communities associated with the SCM. In some size fractions $r b c L$ DNA but no corresponding mRNA was detected suggesting phytoplankton containing such genes were not active or were not actively synthesizing RubisCO mRNA at the time of sampling. Diel variations in $r b c L$ gene expression are now well documented for natural populations (Pichard et al. 1993, 1996). In these studies, relatively low but constant levels of cyano rbcL DNA were found while dramatic variations in $r b c L$ mRNA were observed. In other size fractions, $r b c L$ mRNA but not DNA was detected suggesting a high level of expression from relatively few members of the phytoplankton community.

Low but relatively constant levels of cyano and chromo rbcL DNA were observed at all profile stations. This condition makes association of cyano and chromo rbcL DNA with specific taxonomic groups of phytoplankton more difficult. This may be because DNA concentrations were often near the limit of detection by hybridization. The euphotic zone patterns in RubisCO gene expression (cyano and chromo mRNA) are more consistent with the HPLC pigment signatures for the various taxonomic groups than the DNA data, and are indicative of active metabolism by these groups.

Correlation analysis of the data showed that carbon fixation rates in the various size fractions were highly correlated with cyano rbcL mRNA and less so with chromo mRNA. In euphotic zone profiles carbon fixation was also correlated with Synechococcus abundance. Synechococcus abundance also seemed to determine the mid-morning water column levels of cyano rbcL mRNA. Diel studies of surface water communities dominated by Synechococcus show that this was the time of day that the community exhibits the greatest cyano rbcL mRNA abundance (Pichard et al. 1996). On the other hand, chromo rbcL mRNA was more predominant deeper in the water column and highly correlated to red-fluorescing picoeucaryote abundance. Examination of the combined data by multiple correlation showed that variation in the rate of carbon fixation can be attributed to variations in both cyano and chromo mRNA as well as to chl a biomass.

Numerous studies have demonstrated dramatic differences in taxonomic composition between surface communities and those deep in the euphotic zone (cited in Venrick 1993). The transition between a shallow and deep water phytoplankton assemblage can be very sharp (Venrick 1982), resulting in a pronounced difference in surface and deep water community taxonomic composition. Recently, fine scale structural differences in the phytoplankton community have been demonstrated in the tropical/subtropical SCM (McManus \& Dawson 1994). The genera Synechococcus and Prochlorococcus are just now being recognized as extremely heterogenous groups that exhibit high genetic variation (Wood \& Townsend 1990, Palenik \& Haselkorn 1992, Palenik 1994, Scanlan et al. 1996). Oligonucleotide rRNA targeted probes are currently under development for use in identifying various phytoplankton taxa and could be used for resolving fine scale differences in the phytoplankton taxonomic composition (Simon et al. 1995)

In this study, HPLC pigment analysis of divinyl chlorophyll pigments suggested that Prochlorococcus exhibit their maximum abundance near the SCM; Prochlorococcus were detected throughout the euphotic zone water column with maximum counts found at $50 \mathrm{~m}$ ( 20-fold greater than Synechococcus). The divinyl chlorophyll pigments are known to vary on a cell basis from $0.09 \mathrm{fg}_{\text {cell }}{ }^{-1}$ for surface populations to $1.45 \mathrm{fg} \mathrm{cell}^{-1}$ for SCM populations (McManus \& Dawson 1994) and recent studies indicate that there are at least 2 separate large groupings of Prochlorococcus 
based on chl $a 2 /$ chl b2 ratios and $16 \mathrm{~S}$ rRNA sequences (Moore et al. 1996). Similarly, different types of Prochlorococcus have been detected based on allelic variation of petB/D (photosynthetic chromosomes) in depth profiles from oligotrophic marine water columns (Urbach 1995). Data also suggests that there are at least physiologically (possibly a genetic basis) distinct populations of Prochlorococcus residing at different depths throughout the water column (Campbell \& Vaulot 1994) as well as differences in the chl $a 2 / \mathrm{chl} b 2$ ratios between Mediterranean. North Atlantic, and Sargasso Sea isolates of Prochlorococcus (Partensky et al. 1993, Moore et al. 1995). The Sargasso Sea isolate appears to be able to adjust this chlorophyll ratio under varying light regimes while the Mediterranean and North Atlantic isolates appear to have fixed ratios indicative of some difference between isolates, an observation that seems supported by the 70 to $75 \%$ genetic similarities between strains (Scanlan et al. 1996). While we have shown several Prochlorococcus strains to hybridize well with the cyano rbcL gene probe, other Prochlorococcus strains have been shown to contain a divergent $r b c L$ sequence that is more closely related to those of chemoautotrophic gamma proteobacteria (Shimada et al. 1995) and to another apparently divergent sequence from Synechococcus WH7803 (Watson \& Tabita unpubl). Whether this variation between surface and deep water Prochlorococcus populations is reflected in the $r b c L$ gene sequence is not known.

Not all phytoplankton taxa can be expected to be detected by the broad-specificity probes used in this study. Recent evidence on RubisCO in peridinin containing dinoflagellates suggests that $r b c L$ expression in this group should not be detected using either of these probes since dinoflagellates have now been determined to contain an evolutionarily diverse form II (type II) RubisCO (Morse et al. 1995). Whether this is true for all dinoflagellates is not known. For example, some dinoflagellates contain fucoxanthin in place of peridinin (Andersen et al. 1996), and these have not yet been examined for the form of RubisCO they contain

While the genetic probes employed enabled discrimination between evolutionary lineages of RubisCO. their use does not allow resolution of differences in expression between algae within a lineage. Similar problems are encountered when interpreting phytoplankton pigment signatures where different taxa contain the same pigment (Wright et al. 1991, Millie et al. 1993). The full spectrum of specificity of these probes remains unknown as the probes have not been tested against all phytoplankton taxa, marine chemosynthetic autotrophs, or photosynthetic bacteria. Nonetheless, a number of observations can be made based on the data presented: (1) Coastal environments, such as estuarine outflows, continental shelves, mangrove-fringed lagoons and embayments, and surface water communities show the highest levels of cyano rbcL mRNA. The cyano mRNA is mainly associated with the larger size class ( $>5 \mu \mathrm{m})$ in coastal environments and with the smaller size class $(<1 \mu \mathrm{m})$ in offshore environments. (2) Coastal environments and deep euphotic zone communities (SCM) have the highest levels of chromo rbcL mRNA consistent with their relative phytoplankton taxonomic composition based on HPLC pigment analysis. For coastal environments the chromo mRNA is associated with cells $>5 \mu \mathrm{m}$ while in the deep euphotic zone cells are mainly eucaryotic picoplankton. (3) At of shore oligotrophic environments (Stas 4B and 9) the phytoplankton community was well stratified with peak abundances of different taxa appearing at various depths throughout the euphotic zone. Synechococcus were most abundant in surface waters, Prochlorococcus were most abundant in mid-waters, and picoeucaryotes were present in greatest abundance in the deeper layers of the euphotic zone (SCM). (4) At offshore stations the maximum levels of cyano $r b c L$ mRNA were coincident with the peak abundance of Synechococcus while maximum levels of chromo rbcL mRNA are found deep in the euphotic zone associated with the SCM community. In summary, we have demonstrated differences in cyanobacterial/chlorophyte and chromophyte algae RubisCO gene expression in marine surface water and water column phytoplankton communities in order to understand the spatial dynamics of RubisCO gene expression and its relationship to water column carbon assimilation. Such use of molecular probes is a first approach to elucidating which marine phytoplankton groups are actively transcribing their Calvin cycle genes and thereby contributing to the spatial patterns of water column carbon fixation.

Acknowledgements. This research was supported by National Science Foundation grants OCE9216937 and OCE 9218517, and Department of Energy grants DE-FG0593ER6199 and DE-FG02-93ER61700 to J.H.P. and F.R.T. respectively; a National Aeronautical and Space Administration grant NAS5-30779 to K.C.i and a National Science Foundation grant OCE9417071 to L.C. S.L.P. was supported by a U.S. Geological Survey Coastal Science Fellowship and a Knight Oceanographic Research Fellowship from the USF Dept of Marine Science. Technical assistance was provided by H. G. Williams, J. B. Williams, C. A. Kellogg, and S. Jiang.

\section{LITERATURE CITED}

Andersen RA, Bidigare RR, Keller MD, Latasa M (1996) A comparison of HPLC pigment signatures and electron microscopic observations for oligotrophic waters of the North Atlantic and Pacific Oceans. Deep Sea Res II 43 $517-537$

Buck KR, Chavez FP, Campbell L (1996) Basin-wide distributions of living carbon components and the inverted trophrc 
pyramid of the central gyre of the North Atlantic Ocean, summer 1993. Aquat Microb Ecol 10:283-298

Campbell L, Shapiro LP, Haugen E (1994) Immunochemical characterization of eukaryotic ultraplankton from the Atlantic and Pacific oceans. J Plankton Res 16:35-51

Campbell L, Vaulot D (1994) The importance of Prochlorocococcus to community structure in the central North Pacific Ocean. Limnol Oceanogr 39:954-961

Chesnick JM. Cattolico RA (1993) Isolation of DNA from eukaryotic algae. Methods Enzymol 224:168-176

Chisholm SW, Frankel SL, Goericke R, Olsen RJ, Palenik B, Waterbury JB, West-Johnsrud L, Zettler ER (1992) Prochlorococcus marinus nov. gen. sp.: an oxyphototrophic marine prokaryote containing divinyl chlorophyll $a$ and $b$. Arch Microbiol 157:297-300

Chisholm SW, Olson RJ, Zettler ER, Goericke R, Waterbury JB, Welschmeyer NA (1988) A novel free-living prochlorophyte abundant in the oceanic euphotic zone. Nature 334 $340-343$

Cullen JJ (1982) The deep chlorophyll maximum: comparing vertical profiles of chlorophyll a. Can J Fish Aquat Sci 39: $791-803$

Fogg GE (1995) Some comments on picoplankton and its importance in the pelagic ecosystem. Aquat Microb Ecol 9:33-39

Frischer ME, Thurmond JM, Paul JH (1990) Natural plasmid transformation in a high-frequency-of-transformation marine Vibrio strain. Appl Environ Microbiol 56 $3439-3444$

Glover HE, Campbell L, Prézelin BB (1986) Contribution of Synechococcus spp. to size fractionated primary productivity in three water masses in the Northwest Atlantic Ocean. Mar Biol 91:193-203

Guillard RRL, Ryther JH (1962) Studies of marine planktonlc diatoms 1. Cyclotella nana Husted and Detonula Confervacea (cleve) Gran. Can J Microbiol 8:229-239

Harrison WG (1990) Nitrogen utilization in chlorophyll and primary productivity maximum layers: an analysis based on the f-ratio. Mar Ecol Prog Ser 60:85-90

Holm-Hansen O, Riemann B (1978) Cholophyll a determination: improvements in methodology. Oikos 30:438-447

Jitts HR (1963) The simulated in situ measurement of oceanic primary production. Aust J Mar Freshwat Res 14:139-147

Li WKW (1994) Primary production of prochlorophytes, cyanobacteria, and eukaryotic ultraphytoplankton: measurements from flow cytometric sorting. Limnol Oceanogr 39: $169-175$

Li WKW (1995) Composition of ultraphytoplankton in the central North Atlantic. Mar Ecol Prog Ser 122:1-8

Li WKW, Zohary T, Yacobi YZ, Wood AM (1993) Ultraphytoplankton in the eastern Mediterranean Sea: towards deriving phytoplankton biomass form flow cytometric measurements of abundance, fluoresence, and light scatter. Mar Ecol Prog Ser 102:79-87

Lindell D, Post AF (1995) Ultraphytoplankton succession is triggered by deep winter mixing in the Gulf of Aqaba (Eilat), Red Sea. Limnol Oceanogr 40:1130-1141

Longhurst AR, Harrison WG (1989) The biological pump: profiles of plankton production and consumption in the upper ocean. Prog Oceanogr 22:47-123

McManus GB, Dawson R (1994) Phytoplankton pigments in the deep chlorophyll maximum of the Caribbean Sea and the western torpical Atlantic Ocean. Mar Ecol Prog Ser 113:199-206

Millie DF, Kirkpatrick G.J, Vinyard BT (1995) Relating photosynthetic pigments and in vivo optical density spectra to irradiance for the Florida red-tide dinoflagellate Gymno- dinium breve. Mar Ecol Prog Ser 120:65-75

Millie DF, Paerl HW, Hurley JP (1993) Microalgal pigment assessments using high-performance liquid chromatography: a synopsis of organismal and ecological applications. Can J Fish Aquat Sci 50:2513-2527

Moore LR Goericke R, and Chishom SW (1995) Comparative physiology of Synechococcus and Prochlorococcus: influence of light and temperature on growth, pigments, fluoresence and absorptive properties. Mar Ecol Prog Ser 116: $259-275$

Moore L R, Rocap G, Chisholm SW (1996) Two physiologically distinct types of Prochlorococcus coexist in the North Atlantic. OS22C-14, AGU/ASLO Ocean Sciences meeting, San Diego, Feb. 12-16. EOS 76:82-83

Morse D, Salo1s P, Markovic P, Hastings JW (1995) A nuclearencoded form II RubisCO in dinoflagellates. Science 268 : $1622-1624$

Olson RJ, Chisholm SW, Zettler ER, Altabet MA, Dusenberry JA (1990a) Spatial and temporal distributions of prochlorophyte picoplankton in the North Atlantic Ocean. Deep Sea Res 37:1033-1051

Olson RJ, Chisholm SW, Zettler ER, Armbrust EV (1990b) Pigments, size, and distribution of Synechococcus in the North Atlantic and Pacific Oceans. Limnol Oceanogr 35: $45-58$

Orellana MV, Perry MJ (1992) An immunoprobe to measure RubisCO concentrations and maximal photosynthetic rates of individual phytoplankton cells. Limnol Oceanogr $37: 478-490$

Orellana MV, Perry MJ (1995) Optimization of an immunofluorescent assay of the internal ribulose-1,5-bisphosphate carboxylase (RubisCO) in single phytoplankton celis. J Phycol 31:785-794

Palenik B (1994) Cyanobacterial community structure as seen from RNA polymerase gene sequence analysis. Appl Environ Microbiol 60:3212-3219

Palenik B, Haselkorn R (1992) Multiple evolutionary origins of prochlorophytes, the chlorophyll b-containing prokaryotes. Nature 355:265-267

Partensky F, Hoepffner N, Li WKW, Ulloa O, Vaulot D (1993) Photoacclimation of Prochlorococcus sp. (Prochlorophyta) strains isolated from the North Atlantic and the Mediterranean Sea. Plant Physiol 101:285-296

Paul JH, Myers B (1982) Fluorometric determination of DNA in aquatic microorganisms by use of Hoechst 33258. Appl Environ Microbiol 43:1393-1399

Paul JH, Pichard SL (1995) Extraction of DNA and RNA from aquatic Environments. In: Trevors JD, Van Elsas JD (eds) Nucleic acids in the environment: methods and applications. Springer-Verlag, Berlin, p 153-177

Pichard SL, Campbell L, Kang JB, Tabita FR, Paul JH (1996) Regulation of ribulose bisphosphate carboxylase gene expression in natural phytoplankton communities. I. Diel rhythms. Mar Ecol Prog Ser 139:257-265

Pichard SL, Frischer ME, Paul JH (1993) Ribulose bisphosphate carboxylase gene expression in subtropical marine phytoplankton populations. Mar Ecol Prog Ser 101:55-65

Pichard SL, Paul JH (1991) Detection of gene expression in genetically engineered microorganisms and natural phytoplankton populations in the marine environment by mRNA analysis. Appl Environ Microbiol 51:1721-1727

Pichard SL, Paul JH (1993) Gene expression per gene dose: a specific measure of gene expression in aquatic microorganisms. A.ppl Environ Microbiol 59:451-457

Platt T, Li WKW (eds) (1986) Photosynthetic picoplankton. Can Bull Fish Aquat Sci 214

Prézelin BB, Bıdigare RR, Matlick HA, Putt M, Ver Hoven B 
(1987) Diurnal patterns of size-fractionated productivity across a coastal front. Mar Biol 96:563-574

Prézelin BB, Glover HE, Ver Hoven B, Steinberg D, Matlick HA, Schofield O, Nelson N, Wyman N, Campbell L (1989) Blue-green light effects on light-limited rates of photosynthesis: relationship to pigmentation and productivity estimates for Synechococcus populations from the Sargasso Sea. Mar Ecol Prog Ser 54:121-136

Prézelin BB, Glover HE (1991) Variability in tıme/space estimates of phytoplankton, biomass and productivity in the Sargasso Sea. J. Plankton Res. 13 (supp1):45-67

Scanlan DJ, Hess WR, Partensky F, Newman J, Vaulot D (1996) High degree of genetic variation in Prochlorococcus (Prochlorophyta) revealed by RFLP analysis. Eur J Phycol 31:1-9

Shımada A, Kanai S, Maruyama $\Upsilon$ (1995) Partial sequence of ribulose-1,5-bisphosphate carboxylase/oxygenase and the phylogeny of Prochloron and Prochlorococcus (Prochlorales). J Mol Evol 40:671-677

Simon $N$, LeBot $N$, Dominique $M$, Partensky $F$, Vaulot $D$ (1995) Fluorescent in situ hybridization with rRNA-targeted oligonucleotide probes to identify small phytoplankton by flow cytometery. Appl Environ Microbiol 61 2506-2513

Tett P, Barton ED (1995) Why are there about 5000 species of phytoplankton in the sea? J Plankton Res 17:1693-1704

Urbach E (1995) Evolution and population genetics of Prochlorococcus marinus. PhD dissertation, Massachu-

This article was presented by J. Fuhrman (Senior Editorial Advisor), Los Angeles, California, USA setts Institute of Technology, Cambridge

Venrick EL (1982) Phytoplankton in an oligotrophic ocean: observations and questions. Ecol Monogr 52:129-154

Venrick EL (1993) Phytoplankton seasonality in the central North Pacific: the endless summer reconsidered. Limnol Oceanogr 38:1135-1149

Vernet M, Mitchell BG, Holm-Hansen O (1990) Adaptation of Synehcoccocus in situ determined by varlability in intracellular phycoerythrin-543 at a coastal station off the southern California coast, USA. Mar Ecol Prog Ser 63: $9-16$

Waterbury JB, Willey JM (1988) Isolation and growth of marine planktonic cyanobacteria. Methods Enzymol 167 $100-105$

Wood AM, Townsend D (1990) DNA polymorphism within the WH7803 serogroup of marine Synechococcus spp. (Cyanobacteria). J Phycol 26:576-585

Wright SW, Jeffrey SW, Mantoura RFC, Llewellyn CA, Bjornland T, Repeta D, Welschmeyer N (1991) Improved HPLC method for the analysis of chlorophylls and carotenoids from marine phytoplankton. Mar Ecol Prog Ser 77 $183-196$

Xu HH, Tabita FR (1996) Ribulose-1,5-bisphosphate carboxylase/oxygenase gene expression and diversity of Lake Erie planktonic microorganisms. Appl Environ Microbiol 62:1913-1921

Zar JH (1984) Biostatistical analysis, 2nd edn. Prentice-Hall. Englewood Cliffs, $\mathrm{NJ}$

Manuscript first received: July 31, 1996

Revised version accepted: January 22, 1997 